\title{
INEXISTÊNCIA DE IMPROBIDADE ADMINISTRATIVA PARA O AGENTE PÚBLICO RESPONSÁVEL PELA ORDEM TRIBUTÁRIA SE NÃO HOUVER CRÉDITO CONSTITUÍDO E SE NÃO FICAR DEMONSTRADO A POSTERIORI ATO DE MÁ-FÉ
}

\section{Mauro Roberto Gomes de MatTos*}

I - Introdução. II - Sem crédito tributário constituído não há crime e nem reflexo. inexistência do ato de improbidade administrativa. $-I I I-$ Da improcedência da ação de improbidade administrativa. IV - Princípio da dignidade humana como limitador do indevido manejo da ação de improbidade administrativa. $V-$ Conclusão

\section{$I$ - Introdução}

A Lei $n^{\circ} 8.429 / 92$ regula os atos de improbidade administrativa contra os agentes públicos e possui um caráter aberto, ${ }^{1}$ deixando de definir o que venha a ser ato ímprobo, para apenas estabelecer os seus tipos (arts. 9, 10 e 11).

Não resta dúvida que a interpretação de uma lei "tão aberta" como a presente é preocupante, pois todos sabem que apesar de ter ocorrido uma rápida e radical metamorfose de alguns homens públicos, que sucumbidos pelas facilidades oferecidas pelos seus cargos ou funções resolveram desrespeitar ao erário, existem aqueles que honram suas atribuições através de atos honestos e destinados a construção do interesse público.

* Advogado no Rio de Janeiro. Autor dos Livros: "O Limite da Improbidade Administrativa O Direito dos Administrados dentro da Lei ${ }^{\circ} 8.429 / 92^{\prime \prime}-2^{\circ}$ Ed.. Ed. América Jurídica. "Lei ${ }^{\circ}$ 8.112/90 Interpretada e Comentada", Ed. América Jurídica e "O Contrato Administrativo" — $2^{2}$ Ed., Ed. América Jurídica. Vice Presidente do Instituto Ibero Americano de Direito Público IADP, Membro da Sociedade Latino-Americana de Direito do Trabalho e Seguridade Social, Membro do IFA - Internacional Fiscal Association. Conselheiro efetivo da Sociedade LatinoAmericana de Direito do Trabalho e Seguridade Social.

1 Cf. MATTOS, Mauro Roberto Gomes de., O Limite da Improbidade Administrativa - O Direito dos Administrados dentro da Lei $n^{\circ} 8.429 / 92,2^{2}$ ed., Ed. América Jurídica, 2005, Rio de Janeiro, p. 2.

\begin{tabular}{lll}
\hline R. Dir. Adm., & Rio de Janeiro, 240: 185-203, & Abr./Jun. 2005 \\
\hline
\end{tabular}


Esta modificação que alterou substancialmente o perfil dos valores e princípios de alguns agentes públicos, passando a serem corruptos e inescrupulosos, foi suficiente para a estipulação, pela Constituição Federal (art. $37, \S 4^{\circ}$ ), da necessidade de uma lei capaz de inibir os atos administrativos ímprobos.

Sucede, que o legislador não foi feliz quando estabeleceu uma "lei aberta" e sem a definição do que venha a ser ato de improbidade administrativa. Esta inconcebível omissão legislativa é capaz de confundir ato ilegal, sem o elemento subjetivo do tipo, o dolo, com o ato construído pela má-fé, este sim composto pela devassidão.

É lamentável que uma lei tão importante para a sociedade brasileira não diga o que venha a ser ato ímprobo de agente público, assemelhando-se a norma penal em branco, por possuir conteúdo incompleto, ${ }^{2}$ e cujo "aperfeiçoamento" fica por conta de quem interpreta a lei de improbidade administrativa. A definição de improbidade administrativa não pode ser um "cheque em branco" ou um "recipiente vazio". pois a segurança jurídica que permeia um Estado Democrático de Direito como o nosso não permite essa indefinição jurídica. ${ }^{4}$

Ora, o Estado-segurança (Sicherheitsstaat) ${ }^{5}$ se preocupa com a estabilidade das relações jurídicas, estabelecendo o dever da Lei identificar, com clareza e precisão, os elementos definidores da conduta delituosa. ${ }^{6}$

Estipular apenas os tipos da improbidade, sem definir o que a lei entende como ato ímprobo, gera uma interpretação dúbia, nem sempre fiel aos fatos que norteiam o caso posto ao debate jurídico.

É lamentável esta omissão legislativa, pois ela é capaz de estabelecer, em um primeiro momento, uma falsa imagem de um ato ilegal e desastrado praticado sem o dolo, que possa vir a ser enquadrado na Lei $n^{\circ} 8.429 / 92$.

Os três tipos da improbidade administrativa (enriquecimento ilícito, prejuízo ao erário ou atos que afrontam aos princípios da Administração Pública), sem a definição legal clara e precisa ("conteúdo descritivo") $)^{7}$ do que venha a ser ato ímprobo, gera muitas injustiças, com a possibilidade de manejo indevido da correspondente ação.

Um dos exemplos de ilegalidade no ajuizamento da ação de improbidade administrativa é quando ela é direcionada para o agente público responsável pela

2 A norma legal só gera conseqüência jurídica quando ela é clara e precisa, ou é conectada com outro comando legal a fim de ter eficácia. Por isso, Fábio Konder Comparato esclareceu: “'A lei em branco, muito ao contrário, apresenta-se como norma de conteúdo incompleto. e cujo aperfeiçoamento só é alcançado mediante reenvio a outro diploma normativo. já existente ou a ser futuramente editado." (COMPARATO, Fábio Konder. "Lei Penal em Branco: Inconstitucionalidade de sua Integraçâo das Normas de Nivel Infralegal - Os Crimes de Perigo são Crimes de Resultado". in Direito Público. Estudos e Pareceres. São Paulo. Saraiva. 1996. p. 269.

3 Cf. ANDRADE, Manoel A. Domingues de., Ensaio sobre a Teoria da Imterpretação das Leis, $4^{a}$ ed., Coimbra, 1987, p. 69.

4 Cf. MATTOS, Mauro Roberto Gomes de., ob. cit. ant., p. 3.

5 Cf. HIRSCH, Joaquim. Der Sicherheitssataat, Francfort-sun-main, 1980, p. 55.

6 STF, Rel. Min. Celso de Mello, Ext. No 633/CH, Pleno, DJ 6.04.2001, p. 67.

7 Cf. MATTOS, Mauro Roberto Gomes de., ob. cit. ant., p. 3. 
fiscalização tributária, que lançando ou deixando de lançar crédito tributário do contribuinte, sendo o seu ato concretizado sem má-fé, ou é revisto pelo seu superior e o contribuinte impugnou a respectiva revisão para a esfera superior administrativamente.

Freqüentemente temos nos deparado com ações de improbidade administrativa contra Fiscais do IPTU, Auditores da Receita Federal ou Auditores Estaduais, quando eles concedem benefícios fiscais aos contribuintes que a seguir são revistos pelos seus chefes imediatos. Nessas situações, além da abertura do processo administrativo disciplinar, antes da conclusão do mesmo, é enviada cópia do ato administrativo hostilizado ao Ministério Público, que imediatamente propõe a ação de improbidade administrativa, com esteio em um dos respectivos tipos, elencados nos artigos 9. 10 e 11, da Lei $n^{\circ} 8.429 / 92$, sem aguardar a conclusão da esfera administrativa/tributária.

Exatamente por presenciar tais injustiças, com o dilaceramento de pessoas honestas, indevidamente colocadas no banco dos réus, com sequielas irreversíveis, é que sentimos a necessidade de fazer este estudo sobre as razões jurídicas que impedem o manejo da ação de improbidade administrativa contra os agentes públicos que estão vinculados aos respectivos órgãos tributários.

Tal confusão na interpretação ocorre pelo fato da lei ter o seu alcance "bem aberto", capaz de confundir ato de boa-fé com o ato de má-fé, ou seja, ato ilegal com ato devasso. Não podemos comungar com esta hóstia e por esta razão deixamos expresso o nosso inconformismo com tamanha ilegalidade.

II - Sem crédito tributário constituído não há crime e nem reflexo. inexistência do ato de improbidade administrativa

A ação de improbidade administrativa não pode ser manejada de forma ampla, geral e irrestrita, pois foi concebida para coibir ato devasso e desonesto do agente público, que trás em seu âmago a vontade de lesar ou prejudicar determinado ente de direito público.

Pois bem, o agente público tributário que opina pelo deferimento de pleito do contribuinte, ou de uma restituição, ou até mesmo no sentido de diminuir ou suprimir determinado tributo, bem como, quando se tratar de IPTU acolhe desmembramento das inscrições imobiliárias do interessado, sem má-fé e interpretando a legislação com certa razoabilidade administrativa, não está sujeito à aplicação do contido na Lei ${ }^{\circ} 8.429 / 92$.

Isto porque, o equívoco do agente público, por si só, sem que haja o liame da desonestidade ou da imoralidade não dá azo à falta disciplinar, tendo em vista que falhas ou erros funcionais se configuram em atos anuláveis. Sucede, que hoje em dia, de forma equivocada, qualquer erro de interpretação ou equívoco administrativo possui a presunção errada, antes da devida apuração interna, de que houve fraude $e$ prejuízo ao erário, devendo o servidor ser punido a qualquer custo.

Este açodamento é prejudicial à própria Lei $n^{\circ} 8.429 / 92$, que se enfraquece quando a ação de improbidade administrativa é manejada irresponsavelmente, sem um mínimo de substrato legal. 
A alteração de posicionamento administrativo, que revoga o ato do Auditor Fiscal e promove o lançamento tributário, não é suficiente para configurar uma justa causa para o envio de cópias para o Ministério Público, a fim de que ele promova a ação de improbidade administrativa.

Mormente quando o contribuinte promove impugnação ao ato administrativo que promoveu o lançamento tributário.

Sem o término do processo administrativo fiscal, não há condição de procedibilidade para o ajuizamento da ação de improbidade administrativa, visto que a impugnação do contribuinte ou um futuro recurso podem alterar o indevido enquadramento na Lei $n^{\circ} 8.429 / 92$.

Também inexiste a subsunção penal, pois para a verificação de qualquer um dos ilícitos com repercussão nas esferas penal ou administrativa. é necessário o esgotamento do processo administrativo fiscal.

Aliás, esta ótica já se encontra sedimentada pelo STF, como se verifica no seguinte julgado: ${ }^{8}$

"Crime Tributário - Pendência de Processo Administrativo. Pendente processo administrativo, descabe adentrar o campo penal quer considerada a ação propriamente dita, quer inquérito policial - inteligência do artigo 34 da Lei $n^{\circ}$ 9.249/95. Precedente: Habeas Corpus $n^{\circ}$ 81.611-8/DF, relator ministro Sepúlveda Pertence, julgado em 10 de dezembro de 2003, Plenário."

Por ser um pseudo ilícito material, somente se consuma com o lançamento definitivo, após todo o trâmite administrativo onde não se discute mais o débito tributário perante às autoridades fazendárias competentes:

"Habeas Corpus. Penal. Tributário. Crime de supressão de tributo (Art. $1^{\circ}$ da Lei $\left.n^{\circ} 8.137 / 1990\right)$. Natureza jurídica. Esgotamento da via administrativa. Prescrição. Ordem concedida. 1. Na linha do julgamento do HC 81.611 (rel. min. Sepúlveda Pertence, Plenário), os crimes definidos no art. $1^{\circ}$ da Lei $8.137 / 1990$ são materiais, somente se consumando com o lançamento definitivo. 2. Se está pendente recurso administrativo que discute o débito tributário perante as autoridades fazendárias, ainda não há crime, porquanto "tributo" é elemento normativo do tipo. 3 . Em consequiência, não há falar-se em início do lapso prescricional, que somente se iniciará com a consumação do delito, nos termos do art. 111, I, do Código Penal."9

“1. Prova: alegação de ilicitude da obtida mediante apreensão de documentos por agentes fiscais, em escritórios de empresa - compreendidos no

8 STF. HC n ${ }^{\circ} 84.105 / S P$. Rel. Min. Marco Aurélio, $1^{\text {a }}$ T.. DJ de 13.08.2004, p. 275.

9 STF,HC no 834/RS. Rel. Min. Joaquim Barbosa, la T., DJ de 23.04.2004. p. 24. 
alcance da garantia constitucional da inviolabilidade do domicílio - e de contaminação daquelas derivadas: tese substancialmente correta, mas, dependente de demonstração concreta de que os fiscais não estavam autorizados a entrar ou permanecer no escritório da empresa, o que demanda reexame de fatos e provas, vedado recurso no extraordinário (Súmula 279). Precedente (HC 79.512. Pertence, DJ 16.5.2003). 2. Contraditório e devido processo legal: perícia extrajudicial, realizada na fase do inquérito policial: é da jurisprudência da Corte que "a perícia não é um simples indício e sim prova técnica e. por isso, pode ser considerada pelo julgador na sentença. sem que caracterize cerceamento de defesa, pois o acusado, ciente da sua juntada ao inquérito policial que instruiu a ação penal, poderia pugnar por elidi-la" (v.g. HC 73.647, $2^{\mathrm{a}}$ T., Maurício Corrêa, DJ 6.9.96). 3. Individualização da pena: alegação de que houve desproporcionalidade entre o número de delitos e o aumento imposto pela continuidade delitiva: pretendida ofensa à Constituição que, se houvesse, seria reflexa ou indireta, pressupondo o reexame de legislação infraconstitucional e da prova. inviável no RE. 4. Recurso extraordinário, requisitos específicos e habeas-corpus de ofício. Em recurso extraordinário criminal, perde relevo a inadmissibilidade do RE da defesa, por falta de prequestionamento e outros vícios formais, se, não obstante - evidenciando-se a lesão ou a ameaça à liberdade de locomoção - seja possível a concessão de habeas-corpus de ofício (v.g. RE 273.363, $1^{\text {a }}$ T., Sepúlveda Pertence, DJ 20.10.2000). 5. Crime material contra a ordem tributária (L. 8.137/90, art. $\left.1^{\circ}\right)$ :lançamento do tributo pendente de decisão definitiva do processo administrativo: falta de justa causa para a ação penal, suspenso, porém, o curso da prescrição enquanto obstada a sua propositura pela falta do lançamento definitivo: precedente (HC 81.611, Pleno, 10.12.2003, Pertence, Inf. STF 333)." (g.n. $)^{10}$

Também é adotada esta orientação para ilícito contra o sistema financeiro, pois o princípio é o mesmo, ou seja, pendente o recurso administrativo, não há como se caracterizar irregularidades administrativas, penais ou cíveis, influenciando a instância administrativa sobre as demais, apesar delas serem independentes e autônomas:

"Habeas Corpus". Penal. Processo Penal. Crime contra o Sistema Financeiro
Nacional. Representação. Denúncia. Processo Administrativo. Arquivamen-
to. Ação Penal. Falta de justa causa. Denúncia por crime contra o Sistema
Financeiro Nacional oferecida com base exclusiva na representação do
Banco Central. Posterior decisão do banco determinando o arquivamento
do processo administrativo, que motivou a representação. A instituição
bancária constatou que a dívida, caracterizadora do ilícito, foi objeto de
repactuação nos autos de execução judicial . O Conselho de Recursos do

10 STF, HC n 230020/SP. Rel. Min. Sepúlveda Pertence, la T., DJ de 25.06.2004, p. 29. 
Sistema Financeiro Nacional referendou essa decisão. O Ministério Público, antes do oferecimento da denúncia, deveria ter promovido a adequada investigação criminal. Precisava, no mínimo, apurar a existência do nexo causal e do elemento subjetivo do tipo. E não basear-se apenas na representação do Banco Central. Com a decisão do banco, ocorreu a falta de justa causa para prosseguir com a ação penal, por evidente atipicidade do fato. Não é, portanto, a independência das instâncias administrativa e penal que está em questão. Habeas deferido." "1

Esta sedimentação jurisprudencial do STF se deve ao fato de ser obrigatória a constituição final do crédito tributário que, segundo o art.142, do CTN, é de competência privativa da autoridade administrativa, através do lançamento.

Dessa forma, estando impugnado o lançamento não há crédito tributário constituído, e. via de consequiência, também não existe a figura do ilícito administrativo ou penal, consoante decisão do STF.

Vigora também este entendimento na doutrina, podendo-se extrair da lavra do ínclito mestre Ives Gandra da Silva Martins, ${ }^{12}$ o seguinte posicionamento sobre o que vem descrito no art. 142, do CTN: "Como se percebe, o lançamento tem uma natureza dualística. Ele não constitui a 'obrigação', pois esta já existe antes do lançamento, mas constitui o 'crédito', que outorga o direito à Fazenda Pública de exigir o tributo após a sua constituição. Por isto, tenho dito que o lançamento é um ato que 'declara' a 'obrigação tributária' e 'constitui' o 'crédito tributário', que tem a mesma natureza da obrigação. É um ato declaratório e constitutivo ao mesmo tempo. Ora, o art. 142 é claríssimo - tem eficácia de lei complementar — ao dizer que a constituição do crédito tributário é privativa da autoridade fiscal. Nem o Presidente da República, nem um Ministro do STF, nem um Juiz Federal ou Estadual, nem o próprio legislador federal, estadual ou municipal podem 'constituir' o crédito tributário, pois a lei complementar determina que esta constituição é ação privativa da autoridade fiscal. Pode ocorrer, todavia, que a autoridade que 'constitua' o crédito tributário não o faça corretamente. (...) No Brasil, onde não há "contencioso administrativo'. mas apenas um processo revisional do lançamento, caberá à própria autoridade físcal ou a um colegiado da entidade fiscalizadora proceder à referida revisão. Findo esse processo fará ou não a 'constituição definitiva' do crédito tributário. Em outras palavras, o 'crédito tributário' só será definitivamente constituído conforme jurisprudência da Suprema Corte, no momento em que o processo de revisão do lançamento tiver sido encerrado, com a manutenção do lançamento, total ou parcialmente. A partir deste momento, tem a Administração Pública o direito de exigi-lo do contribuinte."

11 STF, $\mathrm{HC} \mathrm{n}^{\circ}$ 81324/SP, Rel. Min. Nelson Jobim, 2* T., DJ de 23.08.2002, p. 114.

12 MARTINS, Ives Gandra da Silva., "Função privativa da autoridade fiscal de constituir o crédito tributário e declarar a respectiva obrigação - Não há sonegação fiscal sem crédito tributário constituido. Procedibilidade penal e prejudicialidade". in Revista Dialética de Direito Tributário $n^{\circ} 34$, Ed. Dialética, são Paulo, p. 90/91. 
A seguir, o magistral tributarista arremata: ${ }^{13}$ "4) A resposta também é não. Nenhum processo judicial de cobrança pode ser iniciado contra o contribuinte, enquanto o processo administrativo estiver em curso, ressalvadas as ações intentadas para a preservação do patrimônio destinado a responder por obrigações objeto de outras demandas judiciais (Lei ${ }^{\circ} 9.532 / 97$ e Ação Cautelar), mas que não implicam execução fiscal. As duas leis, inclusive, têm sido objeto de contestação sobre sua constitucionalidade, raramente sendo utilizadas. Entendo que, por outro lado. por força dos arts. 145 e 151 do CTN e 83 da Lei $n^{\circ}$ 9.430/95, nenhum processo crime pode ser mantido contra o contribuinte. Iniciada a ação penal, deve ela ser suspensa, por força do art. 93 do CPP, nos únicos termos que justificariam a aplicação da Súmula 609, apresentados pelo voto do Ministro Xavier de Albuquerque, isto é, de sua prejudicialidade. O não-encerramento do processo administrativo é norma prejudicial que justifica a suspensão da ação penal, como determinou o MM Juiz Nelson Bernardes de Sousa, também no curso do prazo prescricional. 5) O acolhimento, na instância administrativa, da pretensão do contribuinte, com a eliminação do pretendido crédito tributário, elide a existência de qualquer crime fiscal. À evidência, essa decisão não é de 'eficácia meramente opinativa', estando eu convencido de que os eminentes julgadores que assim afirmaram - especialistas, indiscutivelmente, em direito penal - não se detiveram no exame de toda a teoria do lançamento e da formação do crédito tributário, que representa o ingresso no mundo administrativo dos efeitos da obrigação tributária da mesma natureza."

Portanto, havendo impugnação administrativa aos lançamentos efetuados, é retirado o elemento subjetivo do tipo do ilícito, levando-se a concluir que a improbidade administrativa não está caracterizada, pois a pendência de recurso na esfera administrativa fiscal por parte do contribuinte esvai a pretensão punitiva do MP.

Destarte, não há ilícito, nem em tese, enquanto não estiver constituído o crédito tributário definitivo.

Por inexistir, nessas situações, o ato de improbidade administrativa, a intempestiva ação de improbidade administrativa é de ser rejeitada, na forma do art. 17, $\S 8^{\circ}$, da Lei $n^{\circ} 8.429 / 92$.

\section{III - Da improcedência da ação de improbidade administrativa}

Nessas situações jurídicas inexiste o ato de improbidade administrativa, tendo em vista que não há a caracterização do dolo ou da má-fé do agente público, sendo que o seu opinativo posicionamento pode ser revisto pelo grau hierárquico superior, sem que necessariamente signifique que houve um ato de devassidão.

A alteração de posicionamento administrativo tributário, prima facie, não é supedâneo para o embasamento de uma futura ação de improbidade administrativa, tendo em vista, dentre outros vários fundamentos, que ainda não houve a constituição de crédito tributário exigível. 
Deve ser ilícita a conduta do agente público (uma conduta de má-fé), com a pura intenção de causar lesão ao erário, com a obtenção de alguma vantagem.

Isto se consuma, após a constituição definitiva do crédito tributário na esfera administrativa.

Este nexo-causal, consistente na conduta ilícita do agente público, que tem como objetivo causar prejuízo ou tentar causar dano ao erário deverá estar inequivocamente caracterizado para o ajuizamento da ação de improbidade administrativa, após o esgotamento da esfera administrativa/tributária.

Em sentido idêntico, Francisco Octávio de Almeida Prado ${ }^{14}$ é categórico, quando afirma: "Para a configuração do ilícito é necessária a presença de dolo, traduzido na consciência da ilicitude da concessão do benefício."

A interpretação da conduta do agente público perante a Lei de Improbidade Administrativa há de ser sistemática, tendo em vista que a lei não visa punir qualquer conduta ilegal, ou melhor dizendo: "Não intenta punir quem, agindo legalmente, por culpa, causa prejuízo ao patrimônio público. Apenas a perda patrimonial decorrente de ilicitude" ${ }^{15}$ é que poderá dar azo ao enquadramento na Lei ${ }^{\circ} 8.429 / 92$.

Assim, para que possa haver a subsunção direta na descrição típica de um ilícito administrativo, não basta a simples causalidade material: exige-se ainda um liame subjetivo que estabeleça a conexão entre a conduta diretamente típica e a participação do agente público. Sendo que a sua participação deverá ser precedida de dolo e de má-fé, ${ }^{16}$ capaz de comprometer a dignidade da função pública.

A boa-fé retira o ato de improbidade administrativa, tendo em vista que: "A lei alcança o administrador desonesto, mas não o inábil." 17

Partindo dessa premissa, a negligência na arrecadação de tributo ou renda, a que alude o inc. $X$, do art. 10, da Lei de Improbidade Administrativa. não pode ser lida desatrelada do seu caput, pois senão qualquer ato equivocado. sem que seja construído com dolo ou má-fé seria confundido com ato devasso, praticado exatamente com esses elementos.

14 PRADO. Francisco Otávio de Almeida. Improbidade Administrativa. Malheiros. 2001. São Paulo, p. 108.

15 PAZZAGLINI FILHO, Marino: ROSA. Márcio Fernando Elias e FAZZIO JÚNIOR. Waldo..

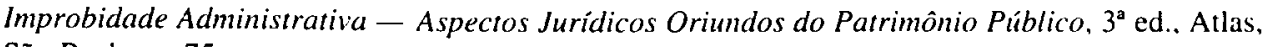
São Paulo, p. 75.

16 Nesse sentido seguem os seguintes julgados: “.(..) Para que seja tipificada a improbidade administrativa. faz-se necessário que tenha havido a caracterização inequívoca de dolo, ou seja, de que houve vontade deliberada do agente em fraudar a lei..." (TJ/MT, Rel. Des. Benedito Pereira do Nascimento, AI $n^{\circ} 8368 / 2002,2^{a}$ C.G. julgado em 20.08.2002. in O Limite da lmprobidade Administrativa - Direito dos Administrados dentro da Lei $n^{\circ} 8.429 / 92$. Mauro Roberto Gomes de Mattos, Ed. América Jurídica, 2004, p. 213). “(...) Como não houve indícios de dolo ou de má-fé, nem foi causado prejuízo financeiro aos cofres públicos, afastada está a hipótese de improbidade administrativa. Sentença confirmada." (TJ/MG, Rel. Des. Jarbas Ladeira, Ap. Cível 1.0000.00.332094-2/000, 6a CC, DJ de 3.10.2003)

17 STJ, Rel. Min. Garcia Vieira, RESP 213994-0/MG, I T., DJ de 27.09.99. 
Não foi em vão que Aristides Junqueira Alvarenga, responsável pela condução do Ministério Público Federal durante vários anos, estabelece que "a desonestidade implica conduta dolosa, não se coaduna pois, com o conceito de improbidade a conduta meramente culposa." 18

Entendemos tal qual Fábio Medina Osório. ${ }^{19}$ entre outros ilustres administrativistas, ${ }^{20}$ que nas relações disciplinares (aí incluída a improbidade administrativa), se aplicam, dentre outros, os princípios da legalidade, tipicidade, culpabilidade e razoabilidade. O que equivale dizer que é obrigatória a demonstração do nexo causal entre o ato tido como ímprobo e a devida subsunção na Lei ${ }^{\circ} 8.429 / 92$.

A descrição da infração administrativa não é uma faculdade discricionária da Administração Pública, se não uma atividade jurídica de aplicação das normas, que exige como pressuposto objetivo o enquadramento do ato tido como ilegal na esfera tributária como infração em tipo predeterminado legalmente, rechaçando-se critérios de interpretação extensiva ou analógica. ${ }^{21}$ A tipicidade da infração disciplinar supõe a coincidência de uma conduta com o suposto fato da norma tipificante.

Dessa forma, o princípio da tipicidade exige que os fatos declarados e provados em procedimento administrativo disciplinar específico se encontrem descritos ex ante em uma norma sancionadora para poder haver a devida investigação. $\mathrm{O}$ ato é vinculado e não discricionário, pois do contrário teríamos a instituição do arbítrio e da perseguição, onde uma mera suspeita, desatrelada de prova material ou de indícios de irregularidades. seriam suficientes para dar início à devassa na vida do agente público. O Estado de Direito 22 que vivemos exige que o princípio da legalidade vigore nessa relação jurídica, onde a previsão de infrações e sanções estejam devidamente estipuladas na lei, sendo que a tipicidade requer algo mais, que é a precisa definição da conduta em texto legal com a consequiente penalidade.

Isto é o mínimo que se espera para garantir o princípio da segurança jurídica, consistente na exigência de uma lex previa e de uma lex certa também na esfera administrativa disciplinar. O direito administrativo moderno virou a página das arbitrariedades que foram verificadas em um passado recente, eis que o império da lei atual exige o mínimo de respeito a todos os cidadãos, que devem ser tratados dignamente, e somente sofrerem investigações ou serem acionados pelo Estado após

18 ALVARENGA, Aristides Junqueira., "Reflexões sobre Improbidade Administrativa no Direito Brasileiro", in Improbidade Administrativa - Questões Polêmicas e Atuais. Malheiros, 2001, São Paulo, p. 88.

19 OSÓRIO, Fábio Medina., Direito Administrativo Sancionador, ed. RT, 2000, São Paulo, p. 223.

20 YELERA, Joaquín Meseguer, La Tipicidad de las Infracciones en el Procedimiento Administrativo Sancionador, Ed. Bosch, 2001, Barcelona, p. 13; COSTA, José Armando da. Incidência Aparente de Infrações Disciplinares, Ed. Fórum, 2004, Belo Horizonte, p. 65.

21 Cf. YEBRA, Joaquín Meseguer., La Tipicidad de las Infracciones en el Procedimiento Administrativo Sancionador, Ed. Bosch, 2001, Barcelona, p. 13.

22 "O princípio básico do Estado de Direito é o da eliminação do arbítrio no exercício dos poderes públicos com a consequiente garantia de direitos dos indivíduos perante esses poderes." (CANOTILHO, José Joaquim Gomes., "Estado de Direito", Cadernos Democráticos, Fundação Mario Soares, Gradiva Publicações, 1999, Lisboa, p. 9. 
a devida tipificação da conduta em um texto legal, mesmo que em tese e em um juizo preliminar, é defeso que haja a invasão de privacidade alheia sem um justo motivo ou uma justa causa. ${ }^{23}$

Como a instância fiscal/tributária é a competente para aferir se houve má-fé com o substrato de intenção dolosa, em que a fraude e a falcatrua são determinantes para a obtenção de um resultado ilícito contra o texto legal, o autor da ação de improbidade administrativa é obrigado a aguardar a conclusão da esfera competente. para após fazer um juízo de valor objetivo, a fím de extrair se há fato punível, em tese, decorrente de ato ilícito do agente público.

Meros erros, ou enquadramentos tributários tidos como indevidos, por si só não permitem ao intérprete concluir que houve o substrato da má-fé.

Oportuno, sobre o que foi dito, é o esclarecimento de Pontes de Miranda:24 "Quem erra faz que não estava para fazer, ou se deixa de fazer o que se havia de fazer, sem que desça, em qualquer das espécies, a verificar se ter havido ato consciente, ou omissão consciente, ou a posteriori, má-fé, ou outro elemento de intenção. Para que aí se vá é preciso que se objetive a expressão 'erro': erro econômico, erro político, erro jurídico, erro religioso, erro moral, erro artístico, erro científico. Então, ocorre dentro de um desses ramos algo de incorreto, a que quase sempre corresponde dever ou obrigação. Por isso, em vez de aludir a erro, alude-se, no direito, ao dolo, à má-fé."

No direito sancionatório não se admite o mero erro ou equívoco do agente público cometido de boa-fé como elemento subjetivo para a punição, tendo em conta que a lei de improbidade administrativa estabelece a necessidade do dolo ou da má-fé25 como elementos de procedibilidade da competente ação.

Como dito, a segurança jurídica retira a tipicidade da conduta do agente público se não ficar inequivocamente demonstrado que houve uma concessão ilícita de vantagens tributárias, antecedidas de má-fé do Auditor Fiscal. Sem essa inequívoca demonstração do nexo-causal entre a concessão indevida de crédito tributário e a má-fé do agente público, a propositura da ação de improbidade administrativa é temerária, devendo a lide ser rejeitada liminarmente, com esteio no art. $17, \S 8^{\circ}$. da Lei $n^{\circ} 8.429 / 92$.

23 Aprofundar em: MATTOS, Mauro Roberto Gomes de. "Necessidade de Justa Causa para a Instauração de Procedimento Administrativo Disciplinar - Impossibilidade do Procedimento Genérico para que no seu curso se apure se houve ou não falta Funcional", Revista Ibero Americana de Direito Público, vol IX, Ed. América Jurídica, $1^{\circ}$ trimestre de 2003, Rio de Janeiro, p. 175.

24 MIRANDA, Pontes de. Comentários ao Código de Processo Civil, tomo I, $5^{2}$ ed., Forense, Rio de Janeiro, ps. 351/352.

25 "Ação civil pública de improbidade administrativa. Ato atentatório aos princípios da administração pública. Falta de comprovação da ocorrência de má-fé. Cadastramento para o auxílio bolsa-escola fora dos padrōes estabelecidos pela administração. Ausência de demonstração de ocorrência de culpa ou dolo. Improbidade administrativa não comprovada. O elemento subjetivo é de suma importância na averiguação do ato, em se tratando de improbidade administrativa. Como não houve indícios de dolo ou má-fé, nem foi causado prejuízo financeiro aos cofres públicos, afastada está a hipótese de improbidade." (TJ/MG, Rel. Des. Jarbas Ladeira, Ap. Cível $\mathrm{n}^{\circ}$ 1.0000.00.332094-2/000, 6* CC, DJ de 3.10.2003). 
Após a presente explanação se constata que a condição de procedibilidade para a ação de improbidade administrativa contra agentes públicos lotados em órgãos tributários, somente poderá ser efetivada após a constituição definitiva do crédito tributário lançado, devendo estar também configurada a má-fé do responsável pelo ato revisto administrativamente.

Este liame, entre revogação administrativa, pelo órgão hierarquicamente responsável e o dolo do Auditor Fiscal é necessário, do contrário, não haverá tipicidade para a subsunção na Lei de Improbidade Administrativa.

Sem tipicidade da conduta do agente público haverá infringência ao princípio da legalidade e da dignidade da pessoa humana, sendo que este último princípio que tomou assento nos diversos textos constitucionais dos países que preconizam o Estado de Direito após o término da Segunda Grande Guerra, onde a preocupação com valores civilizatórios, trouxe a necessidade de voltar o poder das nações para o homem, até então totalmente abandonado, colocado em plano secundário. ${ }^{26}$

Não tardou, por outro lado, que, criada a Organização das Nações Unidas, fosse recuperada e consagrada a Declaração Universal dos Direitos do Homem aprovada e adotada, sob seus auspícios, em 1948, sendo entendida "como um conjunto de normas que visam defender a pessoa humana contra os excessos do poder cometidos pelos órgãos do Estado." 27

No ano seguinte, após a benéfica influência da ONU, a Lei Fundamental de Bonn, da República Federal da Alemanha, a qual se reconhece, geralmente, o pioneirismo da iniciativa, sem embargo de haver a Itália, na sua Constituição de 1947 (art. $3^{\circ}$ ), referido a dignidade social de que igualmente desfrutam todos os cidadãos. Sem a intenção de fazer um inventário exauriente, pode dizer-se que também houve a disseminação desse salutar princípio nas Constituições de Portugal, em 1976, Espanha, em 1978, e Brasil, em 1988. Os anos 90, do mesmo século, marcaram a influência do princípio por numerosos outros países, sobretudo no Leste Europeu. $^{28}$

26 No Preâmbulo da Declaração Universal dos Direitos do Homem foi escrito: " que o desprezo e o desrespeito pelos direitos do homem resultaram em atos bárbaros que ultrajaram a consciência da humanidade; ..."

27 BARRETO, Ireneu Cabral. A Convenção Européia dos Direitos do Homem, Aequitas Editorial Notícias, 1995, Lisboa, p. 15.

28 Para um aprofundamento mais completo, é útil consultar LONDERO, Magdalena. Proteção Internacional dos Direitos do Homem - Tese para concorrer à livre-docência de Direito Internacional Público na UFRJ, Impresso no Jornal do Comércio. 1954, Rio de Janeiro; MORAES, Alexandre de. Direitos Humanos Fundamentais, 5* ed., ed. Atlas, 2003. São Paulo; SOARES, Antônio Goucha, A Carta dos Direitos Fundamentais da Uniāo Européia. A Proteção dos Direitos Fundamentais no Ordenamento Comunitário, Coimbra Editora, 2002, Coimbra; VITORINO, Antônio. Proteç̧ão Constitucional e Proteç̧ão Internacional dos Direitos do Homem: Concorrência ou Complementariedade? Associação Académica da Faculdade de Direito de Lisboa, 1993. Lisboa: 
Segundo Paulo Otero, ${ }^{29}$ o princípio da dignidade da pessoa humana é "dotado de uma natureza sagrada e de direitos inalienáveis, afirma-se como valor irrenunciável e cimeiro de todo o modelo constitucional, servindo de fundamento do próprio sistema jurídico: O Homem e a sua dignidade são a razão de ser da sociedade, do Estado e do Direito."

Para José Afonso da Silva, ${ }^{30}$ o princípio sub oculis é "um valor supremo que atrai o conteúdo de todos os direitos fundamentais do homem, desde o direito à vida. ou "o valor supremo da ordem jurídica" em que a transformou, "reconhecendo a sua existência e a sua eminência", a Constituição."

Extraídas as liçôes de Juarez Tavares. ${ }^{31}$ tem-se que "a ordem jurídica não pode tomar o cidadão como simples meio, mas como fim."

Invocando lição de Günther Dürig, resumiu-lhe o significado originário o Ministro Gilmar Mendes: ${ }^{32} \mathrm{O}$ princípio da proteção à dignidade da pessoa humana "proíbe a utilização ou transformação do homem em objeto dos processos e ações estatais."

Mais uma vez, se faz necessário aderir-se ao pensamento de Juarez Tavares: ${ }^{33}$ "a proteção à dignidade serve de parâmetro ao legislador" na positivação do "pressuposto da culpabilidade".

Por este princípio, torna-se necessário ao regular o exercício do poder sancionatório a sólida demonstração, prima facie, de que a acusação não pode ser temerária ou leviana. ela deve ser baseada em um mínimo de prova e de solidez jurídica. Devendo a acusação fundar-se em robustos elementos jurídicos e em provas cabais, para que não ocorra excesso ou abuso de poder do direito de acionar.

Visa. portanto, a dignidade da pessoa humana estabelecer a mínima garantia de que o direito público fornecerá " adequada proteç̧ão jurídica aos particulares contra os atropelos, as arbitrariedades, as discriminações, as perseguições políticas, que faz em relação aos cidadãos." 34

Ou, como averbado sensatamente pelo Min. Victor Nunes Leal, ${ }^{35}$.. o poder de denúncia não existe para atormentar as pessoas." Nos dias de hoje e sob o primado da proteção à dignidade da pessoa humana, não há sequer como levar a sério uma

SILVA, José Afonso da. "Cidadania e Dignidade da Pessoa Humana", Revista da Procuradoria da Repuiblica, 9/119-126, 122-123.

29 OTERO, Paulo. Legalidade e Administração Pública. O Sentido da Vinculaşão Administrativa à Juridicidade. Almedina, 2003. Lisboa, p. 254.

30 SILVA, José Afonso da. A dignidade da Pessoa Humana como Valor Supremo da Democracia, Revista de Direito Administrativo - RDA, 212/89-94, Ed. Renovar, Rio de Janeiro, 2001, p. 92.

31 TAVARES, Juarez. Critérios de Seleção de Crimes e Cominação de Penas, Revista Brasileira de Ciências Criminais, RT, número especial de lançamento, São Paulo, p. 78.

$32 \mathrm{STF}$, voto no Min. Gilmar Mendes no $\mathrm{HC} \mathrm{n}^{\circ} 81.990,2^{\mathrm{a}} \mathrm{T}$., julgado em 15.10.2002, Rel. Min. Carlos Velloso. Ementário STF 2121-16/3322-3340.

33 TAVARES, Juares. cit. ant., p. 77.

34 AMARAL. Diogo Freitas do. Estudos de Direito Píblico e Matérias Afins. vol. 1. Almedina, 2004, Lisboa, p. 620.

$35 \mathrm{STF}, \mathrm{HC} \mathrm{n}^{\circ} 42.697 . R T J 35 / 531$. 
ação de improbidade administrativa que é distribuída sem que ocorra o julgamento definitivo da última instância da esfera hierárquica administrativa, onde ocorra a constituição do crédito tributário, com a inequívoca demonstração de que houve a má-fé do agente público responsável pelo ato revisto, após o devido processo legal, com a garantia da ampla defesa a que impõe o art. $5^{\circ}, \mathrm{LV}$, da CF.

Atinge o status dignitatis do agente público, quando ele é vítima de uma impotente acusação, baseada em posição jurídica ainda não estabilizada pelo órgão administrativo competente. Sendo certo. que pela simples revogação de um posicionamento adotado anteriormente, sem a demonstração da má-fé. consistente no dolo, não há que se falar em ação de improbidade administrativa.

É preciso que se dê um basta nas ações de improbidade administrativa irresponsáveis, onde o subscritor da exordial, sem nenhum escrúpulo. acusa mesmo não tendo base de sustentação ou prova cabal de que houve um ato ímprobo.

A dignidade da pessoa humana "é um valor espiritual e moral inerente à pessoa" 36 , devendo ser preservado, em todos os sentidos, "o direito à vida privada, à intimidade, à honra, à imagem, entre outros." ${ }^{37}$

Sendo certo que "o sistema jurídico hodierno vive a denominada fase do pós-positivismo ou Estado principiológico na lição de Norberto Bobbio, de sorte que, na aplicação do direito ao caso concreto é mister ao magistrado inferir a ratio essendi do princípio maior informativo do segmento jurídico sub judice. Conseqüentemente, a aplicação principiológica do direito implica em partir-se do princípio jurídico genérico ao específico e deste para a legislação infraconstitucional, o que revela, in casu, que a solução adotada pelo Tribunal a que adapta-se ao preceito constitucional da defesa da dignidade da pessoa humana." 38

Essa salutar evolução constitucional (art. $1^{\circ}$, III) trouxe para o Poder Judiciário a responsabilidade de preservar eficaz o princípio da dignidade da pessoa humana, como "fundamento do próprio Estado Democrático de Direito, que constitui a República Federativa do Brasil." 39

Ciente de sua indelegável missão constitucional, o Poder Judiciário não tem se furtado a conter pseudos discriçionarismos administrativos, tendo em vista que não há poder maior que os direitos consagrados na Magna Carta:

$*(\ldots)$

2. Releva notar que uma Constituição Federal é fruto da vontade política nacional, erigida mediante consulta das expectativas e das possibilidades do que se vai consagrar, por isso cogentes e eficazes suas promessas, sob pena de restarem vãs e frias enquanto letras mortas no papel. Ressoa inconcebível que direitos consagrados em normas menores como Circulares, Portarias,

36 MORAES, Alexandre de. Constituição do Brasil Interpretada. $4^{a}$ ed., Atlas. 2004, ps. 4/5.

37 MORAES, Alexandre de. Ob. cit. ant.ps. 4/5.

38 STJ. Rel. Min. Luiz Fux, REsp. 677603/PB, $1^{\mathrm{a}}$ T., DJ de 25.04.2005. p. 249.

39 STJ, Rel. Min. Eliana Calmon. REsp 707137/PR. $2^{\text {a }}$ T., DJ de 18.04.2005. p. 298. 
Medidas Provisórias. Leis Ordinárias tenham eficácia imediata e os direitos consagrados constitucionalmente, inspirados nos mais altos valores éticos e morais da nação sejam relegados a segundo plano. Trata-se de direito com normatividade mais do que suficiente, porquanto se define pelo dever. indicando o sujeito passivo. in casu, o Estado.

3. Em função do princípio da inafastabilidade consagrado constitucionalmente. a todo direito corresponde uma ação que o assegura, sendo certo que todos os cidadãos residentes em Cambuquira encartam-se na esfera desse direito, por isso a homogeneidade e transindividualidade do mesmo a ensejar a bem manejada ação civil pública.

4. A determinação judicial desse dever pelo Estado, não encerra suposta ingerência do judiciário na esfera da administração. Deveras, não há discricionariedade do administrador frente aos direitos consagrados, quiçá constitucionalmente. Nesse campo a atividade é vinculada sem admissão de qualquer exegese que vise afastar a garantia pétrea.

5. Um país cujo preâmbulo constitucional promete a disseminação das desigualdades e a proteção à dignidade humana, alçadas ao mesmo patamar da defesa da Federação e da República, não pode relegar a saúde pública a um plano diverso daquele que o coloca, como uma das mais belas e justas garantias constitucionais.

6. Afastada a tese descabida da discricionariedade, a única dúvida que se poderia suscitar resvalaria na natureza da norma ora sob enfoque, se programática ou definidora de direitos.

7. As meras diretrizes traçadas pelas políticas públicas não são ainda direitos senão promessas de lege ferenda, encartando-se na esfera insindicável pelo Poder Judiciário, qual a da oportunidade de sua implementação.

8. Diversa é a hipótese segundo a qual a Constituição Federal consagra um direito e a norma infraconstitucional o explicita, impondo-se ao judiciário torná-lo realidade, ainda que para isso, resulte obrigação de fazer, com repercussão na esfera orçamentária.

9. Ressoa evidente que toda imposição jurisdicional à Fazenda Pública implica em dispêndio e atuar, sem que isso infrinja a harmonia dos poderes, porquanto no regime democrático e no estado de direito o Estado soberano submete-se à própria justiça que instituiu. Afastada, assim, a ingerência entre os poderes, o judiciário, alegado o malferimento da lei, nada mais fez do que cumpri-la ao determinar a realização prática da promessa constitucional (...)" 
O princípio da dignidade da pessoa humana possui assento em todos os ramos do direito, em face da sua projeção constitucional.

Nesse sentido, o Direito Penal tem sido favorecido, por igual, com claras incidências do princípio. Deu-se numa delas há uma década, a propósito de tortura, que o Supremo Tribunal definiu "como prática inaceitável de ofensa à dignidade da pessoa" ${ }^{40}$ Recentemente, há pouco mais de um ano, quando lhe coube apreciar longamente a rumorosa questão das discriminações contra judeus, o STF qualificouas como crime de racismo, vinculando a uma "concepção atentatória dos princípios nos quais se erige e se organiza a sociedade humana, baseada na respeitabilidade e dignidade do ser humano e de sua pacífica conveniência no meio social." ${ }^{41}$

Em outro memorável julgado do STF, o Min. Gilmar Mendes, ${ }^{+2}$ refutou "denúncias genéricas, que não descrevem os fatos na sua devida conformação" por não se coadunar "com os postulados básicos do Estado de Direito" violando também o "princípio da dignidade da pessoa humana."

O mesmo princípio mereceu destaque no excesso de prazo de decisão cautelar, ofensiva ao postulado constitucional da dignidade da pessoa humana, tendo em vista que é direito fundamental do indivíduo ter à resolução do litígio, sem dilações indevidas (CF, art. $5^{\circ}, \mathrm{LXXVIII),} \mathrm{e} \mathrm{com} \mathrm{todas} \mathrm{as} \mathrm{garantias} \mathrm{reconhecidas} \mathrm{pela} \mathrm{Magna}$ Carta, inclusive a de não sofrer arbítrio da coerção estatal. Nesse sentido, o eminente Min. Celso de Mello, ${ }^{43}$ deixou registrado: "A duração prolongada, abusiva e irrazoável da prisão cautelar de alguém ofende, de modo frontal, o postulado da dignidade da pessoa humana, que representa - considerada a centralidade desse princípio essencial (Cf, art. $1^{\circ}$, III) - significativo vetor interpretativo vigente em nosso país e que traduz, de modo expressivo, um dos fundamentos em que se assenta, entre nós, a ordem republicana e democrática consagrada pelo sistema de direito constitucional positivo. Constituição / Art. $5^{\circ}$, incisos LIV e LXXVIII). EC 45/2004. Convenção Americana sobre Direitos Humanos (art. $7^{\circ}, n^{\text {os }} 5$ e 6 )."

40 STJ. Rel. Min. Celso Mello, HC 70.389, Pleno, RTJ 178/1168.

41 STF, Rel. Min. Maurício Corrêa, HC n 82.424/RS, Pleno, DJ de 19.03.2004, p. 17.

42 Assim ficou ementado o v. acórdão: "Habeas Corpus. Superior Tribunal de Justiça. Recebimento de denúncia. Constrangimento Ilegal. Alegação de Inépcia da denúncia quanto ao crime de roubo. 1 - A técnica da denúncia (art. 41 do Código de Processo Penal) tem merecido reflexão no plano da dogmática constitucional, associada especialmente ao direito de defesa. Precedentes. 2 Denúncias genéricas, que não descrevem os fatos na sua devida conformação, não se coadunam com os postulados básicos do Estado de Direito. Violação também do princípio da dignidade da pessoa humana. 3 - A denúncia sob exame utiliza-se de um silogismo de feiçāo fortemente artificial para indicar o paciente como autor intelectual do roubo. A decisão do Superior Tribunal de Justiça pelo recebimento da denúncia nada acrescentou em relação ao crime de roubo. 4 - Deferimento da ordem para anular a denúncia quanto à atribuição ao paciente da conduta prevista no art. 157 do Código Penal, ressalvados os votos vencidos da Min. Ellen Gracie e do Min. Joaquim Barbosa." (STF, Rel. p/ acórdão Min. Gilmar Mendes. HC n 84768/PE, 2 T., julgado em 8.03.2005, DJ de 27.05.2005).

43 STF, Rel. Min. Celso de Mello. HC $n^{\circ}$ 85237/DF, Pleno, julgado em 17.03.2005, DJ de 29.04.2005. 
Também administrativa é a índole de significativa aplicação do princípio sub examem, utilizado pelo STF para impedir a exploração iniqua. pelo homem. do trabalho do homem, cronicamente propiciada pelo Município do Rio de Janeiro por insólito sistema de licenciamento de táxis e credenciamento de taxistas, que ficou assim ementado: "(...) Sendo fundamento da República Federativa do Brasil a dignidade da pessoa humana, o exame da constitucionalidade de ato normativo faz-se considerada a impossibilidade de o Diploma Maior permitir a exploração do homem pelo homem (...)" 44

Nesse último julgado, ficou estabelecido que a "Administração Pública submete-se, nos atos praticados, e pouco importando a natureza destes, ao princípio da legalidade."

O grau de importância desse julgado é inegável. pois cai o "véu" do ato administrativo discricionário, que para grande parte da doutrina nacional não poderia ser analisado quanto ao seu conceito de oportunidade e de conveniência.

Com o fim do "império da lei", que vincula-se diretamente às normas e princípios constitucionais. o direito administrativo constitucional permite ao Poder Judiciário que verifique a zona de livre exercício da Administração para que ela fique vinculada aos direitos fundamentais da sociedade, elencados como garantias indissociáveis de todos.

Assim. os atos administrativos, discricionários ou não..$^{+5}$ deverão preservar o princípio da dignidade da pessoa humana em todos os seus sentidos e formas, para que não ocorram abusos intoleráveis do Poder Público.

E, por fim, por inexistir ato de má-fé do Administrador Público de Diadema, que agindo de boa-fé na tentativa de ajudar o Município vizinho de Avanhandava a solucionar um problema iminente de saúde pública gerado por contaminação na merenda escolar, dispensou a prática de formalidades licitatórias que poderiam colocar em risco a vida, a integridade das pessoas, bens e serviços, ante o retardamento da prestação necessária. Com base no cânone da dignidade da pessoa humana, dentre outros princípios, o $\mathrm{STJ}^{46}$ rejeitou iniciativa do Ministério Público de ingressar com pedido de improbidade administrativa contra agente público, como se infere da longa ementa: "Ação de Improbidade Administrativa. Ausência de má-fé do Administrador Público. 1. A Lei 8.429/92 da Ação de Improbidade Administrativa, que explicitou o cânone do art. $37, \S 4^{\circ}$ da Constituição Federal, teve como escopo impor sanções aos agentes públicos incursos em atos de improbidade nos casos em que: a) importem em enriquecimento ilícito $\left(\right.$ art. $\left.9^{\circ}\right)$; b) que causem prejuízo ao erário público (art. 10); c) que atentem contra os princípios da Administração Pública (art. 11),

4 STF. Rel. para Acórdão Min. Marco Aurélio, RE 359.444/RJ. Pleno, j. 24.03.2004. Ementário STF 2153-7/1261-1309.

45 Cf. MATTOS. Mauro Roberto Gomes de. A Constitucionalização do Direito Administrativo e Controle de Mérito (Oportunidade e Conveniência) do Ato Administrativo Discricionário pelo Poder Judiciário, Jus Navigandi. Teresina, a. 9, n. 686, 22 mai. 2005. disponível em: http:// wwwl.jus.com.br./doutrina/texto.asp?id=6756.

t6 STJ, Rel. Min. Luis Fux. REsp.480387/SP. 1" T., DJ de 24.05.2004. p. 163. 
aqui também compreendida a lesão à moralidade administrativa. 2. Destarte, para que ocorra o ato de improbidade disciplinado pela referida norma, é mister o alcance de um dos bens jurídicos acima referidos e tutelados pela norma especial. 3. No caso específico do art. 11, é necessária cautela na exegese das regras nele insertas, porquanto sua amplitude constitui risco para o intérprete induzindo-o a acoimar de ímprobas condutas meramente irregulares, suscetíveis de correção administrativa, posto ausente a má-fé do administrador público e preservada a moralidade administrativa. 4. In casu, evidencia-se que os atos praticados pelos agentes públicos, consubstanciados na alienação de remédios ao Município vizinho em estado de calamidade. sem prévia autorização legal, descaracterizam a improbidade strictu senso, uma vez que ausentes o enriquecimento ilícito dos agentes municipais e a lesividade ao erário. A conduta fática não configura a improbidade. 5. É que comprovou-se nos autos que os recorrentes, agentes políticos da Prefeitura de Diadema, agiram de boa-fé na tentativa de ajudar o município vizinho de Avanhandava a solucionar um problema iminente de saúde pública gerado por contaminação na merenda escolar, que culminou no surto epidêmico de diarréia na população carente e que o estado de calamidade pública dispensa a prática de formalidades licitatórias que venha a colocar em risco a vida, a integridade das pessoas, bens e serviços, ante o retardamento da prestação necessária. 6 . É cediço que a má-fé é premissa do ato ilegal e ímprobo. Consectariamente, a ilegalidade só adquire o status de improbidade quando a conduta antijurídica fere os princípios constitucionais da Administração Pública coadjuvados pela má-fé do administrador. A improbidade administrativa. mais que um ato ilegal, deve traduzir, necessariamente, a falta de boa-fé, a desonestidade. o que não restou comprovado nos autos pelas informações disponíveis no acórdão recorrido, calcadas, inclusive, nas conclusões da Comissão de Inquérito. 7. É de sabença que a alienação da res publica reclama, em regra, licitação. à luz do sistema de imposições legais que condicionam e delimitam a atuação daqueles que lidam com o patrimônio e com o interesse públicos. Todavia, o art. 17. I, "b". da lei 8.666/93 dispensa a licitação para a alienação de bens da Administração Pública, quando exsurge o interesse público e desde que haja valoração da oportunidade e conveniência, conceitos estes inerentes ao mérito administrativo, insindicável, portanto, pelo Judiciário."

Portanto, pelo princípio da dignidade da pessoa humana, o Poder Público não poderá ser irresponsável ao ponto de manejar ações de improbidade administrativa sem um mínimo de plausibilidade jurídica, pois o poder de acionar não é discricionário, ele deve estar em conformidade com o texto legal, sendo defesa a invasão de privacidade alheia.

\section{$V-$ Conclusão}

Após todo o argumentado, se constata que o agente público responsável pela ordem tributária possui uma margem de liberdade quando da sua atuação profissional. 
Dentro desse contexto, quando ele lança ou deixa de lançar determinado crédito tributário, ou altera, no caso do IPTU, cadastro de contribuinte, dentro de uma razoável convicção profissional, construída de boa-fé. não há que se falar em ato ímprobo do agente público.

Esse fundamento toma valor quase que absoluto, quando o ato administrativo praticado pelo Auditor Fiscal, apesar de ter sido revisto pelo seu superior hierárquico. foi impugnado pelo contribuinte, tendo em vista que a falta de constituição definitiva do crédito tributário retira a tipicidade de qualquer irregularidade, quer no campo penal, quer na esfera administrativa.

Como compete privativamente à autoridade administrativa constituir o crédito tributário (art. 142, do CTN), o Ministério Público deverá, como condição de procedibilidade aguardar o desfecho da última instância interna, para verificar se existe materialidade, objetivando ingressar com uma futura ação de improbidade administrativa ou não.

Inobstante tal esgotamento da instância competente. caso não seja mantida a alteração do posicionamento primitivo do Auditor Fiscal, deverá estar condicionada à verificação do ato de improbidade administrativa a caracterização da má-fé e do dolo, elementos imperiosos para a subsunção na Lei $n^{\circ} 8.429 / 92$. Mero equívoco ou ato praticado dentro da boa-fé não permite que se conclua que houve improbidade administrativa. Do contrário, esse raciocínio iria preconizar uma raça humana infalível, onde somente a perfeição é que iria reinar, não sendo admitido o erro ou o equívoco perpetrados de boa-fé.

Sabemos que o erro é possível, e a Lei de Improbidade Administrativa não é posta para coibir os equívocos praticados por agentes públicos de boa-fé e sim, para extirpar os atos devassos e construídos de forma imoral e que fiquem invencivelmente demonstrados. Há um limite bem grande entre o ato administrativo desastrado e o ato administrativo desleal.

O princípio da dignidade da pessoa humana não permite que o Poder Público aniquile a vida e a intimidade das pessoas, de forma leviana e desatrelada com a legalidade.

Para tanto, a sociedade não poderá mais permitir o uso de poder como forma de aviltamento dos direitos e das garantias individuais de todos.

Se os Auditores Fiscais não tiverem a mínima garantia de que quando eles agem de boa-fé estarão imunes a qualquer tipo de pressão ou punição, eles serão obrigados a efetuar o lançamento tributário, mesmo que entendam não haver elementos para fazê-lo. Ora, a liberdade profissional é um dos princípios fundamentais que guarnece o Estado de Direito. Sendo certo que este valor não poderá ser colocado sob suspeita quando o Ministério Público inverte o princípio da presunção de inocência. e resolve desconfiar de todos os atos públicos, como se eles fossem ímprobos, até que o agente público prove ao contrário.

Este não é o Ministério Público com o qual a sociedade sonha. pois como defensor da moralidade pública e fiscal da lei, não pode vulgarizar seus atos com infundadas e injustas acusações. 
Assim, concluímos que inexiste ato de improbidade administrativa para o agente público responsável pela ordem tributária se não houver crédito tributário constituídos se não ficar demonstrado a posteriori manifestação de má-fé do responsável pelo respectivo ato. É necessário este binômio para que não ocorra uma lide temerária, contrária ao plasmado da dignidade da pessoa humana. 


\section{Abuso do Direito nos Contratos de Consumo}

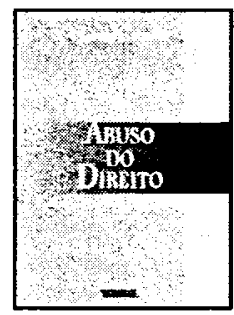

\author{
Heloisa Carpena \\ Ref. 0344 \\ Brochura \\ 271 págs. \\ Form. $14 \times 21$ \\ 2001 \\ ISBN 85-7147-290-4
}

Esta obra compreende o estudo do abuso do direito, desde as origens do instituto até sua aplicação pelos tribunais brasileiros. A teoria do ato abusivo é analisada como fenômeno de relativização dos direitos subjetivos, que passam a ser funcionalizados de acordo com os princípios que regem e fundamentam o ordenamento jurídico, dentre eles, o da dignidade da pessoa humana.

\section{A Responsabilidade Civil do Fornecedor de Produtos pelos Riscos do Desenvolvimento}

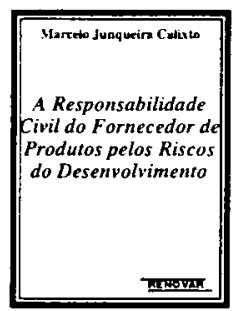

\section{Marcelo Junqueira Calixto}

Ret. 507

Brochura

278 págs.

Form. $13,5 \times 21$

2004

ISBN 85-7147-451-6

São analisados aqui os conceitos fornecidos pelo Código de Defesa do Consumidor e os pressupostos da responsabilidade do fornecedor, quais sejam, o defeito do produto, o dano e o nexo causal entre defeito e dano. Passando ao estudo das excludentes de responsabilidade, a dissertação encontra o seu tema central no exame de uma possivel excludente, aquela fundada nos chamados riscos do desenvolvimento.
O Abuso do Direito e as Relaçōes Contratuais

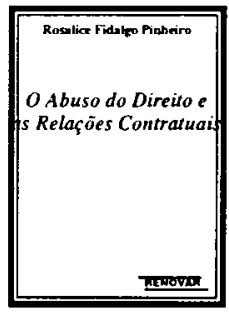

Rosalice Fidalgo Pinheiro

Ref. 0402

Brochura

464 págs.

Form. 13,5×21

2002

ISBN $85-7147-835-X$

Ao fixar sua análise no campo das relações contratuais, a autora identifica na autonomia privada e no direito subjetivo cristalizados em torno de interesses individuais os elementos de base para o desenvolvimento do abuso do direito. A percepção da doutrina, no que se refere à dificuldade de uma definição atual do abuso do direito, serve-lhe de impulso para que examine, criticamente, a metodologia clássica do direito privado.

\section{O Direito do Consumidor na Era da Globalização A descoberta da cidadania}

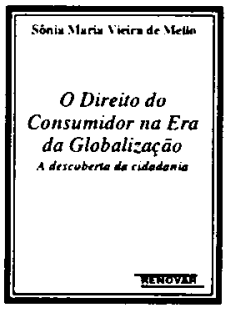

Sônia Maria Vieira de Mello

Ref. 0180

Brochura

172 págs.

Form. $13,5 \times 21$

1998

ISBN 85-7147-088-X

Neste livro, a autora expōe como o consumidor, nesta era de produção global, torna-se consideravelmente vulnerável diante das práticas perpetuadas pelos fornecedores de bens e serviços, muito mais bem informados, fundamentados e assessorados, para os embates mercadológicos. Por fim, analisa as perspectivas que se abrem aos consumidores no Mercosul e em nível internacional. 